\title{
The Continual Cultural, Societal and Religious Relevance of Augustine's City of God
}

\author{
Anna M. $\operatorname{Cox}^{1}$ \\ ${ }^{1}$ M.A. in Political Science in American Government with graduate certificate in Ancient/Classical History from \\ American Public University, United States \\ Correspondence: Anna M. Cox, M.A. in Political Science in American Government with graduate certificate in \\ Ancient/Classical History from American Public University, United States.
}

Received: January 5, 2018

doi:10.11114/ijsss.v6i4.3095
Accepted: February 26, 2018

Available online: March 12, 2018

\begin{abstract}
In every culture and society there are basic fundamental, relevant aspects that are at the core of that society and culture. It is through one of Christianity's greatest Bishops and writer, St. Augustine, and his work The City of God that his metaphor of the heavenly and the Earthly City examines some the most fundamentally profound aspects to a society and culture. It is through examining The City of God that one can see how profoundly and fundamentally influential and relevant these aspects of civil obedience, natural law, justice, virtue, free will and grace are in medieval history and religion. Furthermore in such an evaluation of The City of God it is evident that Augustine's work of the City of God and these fundamentally influential and relevant cultural and societal aspects in medieval times are arguably equally as influential and revenant in modern times, society and culture as they were during St. Augustines day and Medieval times, culture and society.
\end{abstract}

Keywords: St Augustine, The City of God, the heavenly city, the earthly city, civil obedience and society, natural or human law, justice, virtue, free will, grace

\section{Introduction}

In the pages of the Medieval Era in history there is a vast amount of written material that fill these pages and the history of the Medical Europe which provides much to consider. Encompassed in these pages of Medieval history are the profoundly influential areas of Medieval politics, societal components and religious aspects. In examining specifically the facet of religion during the Medieval Era one of the most fundamentally and profoundly significant individuals was the religious leader Bishop Augustine of Hippo. Augustine during his life was a orator, professor, scholar, philosopher, writer and clergyman. Augustine's life and work produced a most extensive and immensely influential imprint on his day, the culture, social and religious spheres of his day and for all of future religious eras in history to come.

Arguably Augustine's paramount, renowned and influential work was City of God. This classic influential religious text was Augustine's message that evolved from his own journey and search for truth and faith. The message of his text he wrote to the people of his day as in way of explaining the reasonings and workings of God, the Christian faith and the events of his day. Augustine's text City of God was immensely influential and relevant during his day and it is equally relevant for political, cultural, religious, societal and historical modern day. In conducting a through examination of this text with the intended purpose of providing a more exhaustive comprehension of the City of God much consideration will be given to the life and journey of Augustine, defining the theological terms and themes of the text, the historical framework of the City of God and some of the specific fundamental relevant themes of the City of God such as civil society and obedience, justice, virtue, free will, grace and also the relevance of Augustine's work to modern day society, times and history.

\section{Augustine Life's Journey and Work}

In one's pursuit of understanding the City of God one must understand the author himself and his own life and journey. Augustine was a philosopher and theologian during the early church and his writings profoundly influenced the development of Western philosophy and Christianity. Augustine is considered to be one of the most significant Fathers in the church and his writings during the Patristic period comprises of Confessions and the City of God. According to Fortin Augustine did not consider himself a philosopher but first and foremost a theologian. In his writings his highest 
principles were taken not from reasons but from the scared Scriptures. (Fortin,1963) Augustine's journey begins in 354 in Taagaste in North Africa where he was born. A good education was highly valued and believed in by his parents who ensured that he received one regardless of the sacrifice. During the day of Augustine higher education he was training in oratory.(G.R. Evans 1984) Moreover during this time it was a common and fashionable cultural practice for individuals to venture on intellectual journeys of faith. According to G.R. Evans searching for and going on quests of an intellectual and spiritual nature would be a theme in Augustine's life for his mother was a Christian while his father was a pagan, although only to make a deathbed profession of faith, thus most of Augustine's earlier life was occupied with the seeking of truth, religious question and the struggle of finding his direction and faith. (G.R. Evans 1984)

A profoundly significant milestone in Augustine's journey to faith came in late August of 386. G.R. Evans author of the introduction in translation of Augustines' City of God describes this monumental turning point in Augustines life as follows: "In late August 386, still in this period of spiritual turmoil, Augustine sat down one day in a garden with the book of Romans in his hands. He wept with frustration and pain, 'in the bitterness of my heart' as he described it. He says that he heard a child's voice from the other side of the wall singing or saying. 'Take and read.' He seized the copy of Romans and opened it and 'I read in silence the first thing my eye fell on,' he says, This was the passage in Romans 13: 13 -14, which he quotes. It calls not he reader to run away frame life of sepal indulgence and to 'put not eh Lord Jesus Christ'. 'I did not need to read further,' he say. 'As soon as I came to the end of that sentence it was as thought the light of security flooded me and all my doubts fell away. His life was transformed. Everything fell int place; the strain and anxiety left him and from hat time on h was a committed Christian. (G.R. Evans 1984) Consequential to his conversion and baptism in 387 Augustine continues on his new journey of faith by creating and developing his approach to theology and philosophy that accommodated diverse and eclectic methods and perspectives. Believing that grace in Christ was indispensable to human freedom, he helped formulate the doctrine of original sin and made seminal contributions to the development of just war theory.

The end of Augustine's journey and life would come in 430 at the age of 76 thus bringing to a close his journey of faith, his influential life's work and his post as Bishop of Hippo. During Augustine's lifetime his influential reach was more expansive and extensive than the local territory of North Africa which was a direct result of his profoundly powerful writings and compelling quality of his preaching and teaching. (G.R.Evans 1984) Possidius Bishop of Calama and good friend to Augustine was responsible for the recording of Augustine's later life and he admired greatly Augustine's powerful intellect, his ability as a stirring orator and his efforts in defending the Christian faith. Augustine is regarded by the Catholic church and the Anglican community as a saint and the preeminent Doctor of the church. Similarly many protestants in particularly Calvinists consider Augustine to be one theological fathers of the Protestant Reformation as a consequence of his teachings regarding divine grace and salvation.

\section{A Defining Description of Augustine's City of God}

Considering the life, journey and work of Augustine one is provided much understanding and evidence to the extensive and expansive paramount influence and relevance Augustine had and continues to have. Also having knowledge of Augustine's life provides much insight into the origins, structure of, purpose, intent and meaning of his greatest work the City of God the. In conjunction with the Confessions Augustine is best known for his most influential work the City of God. Pollmann states that The City of God is known for its diversity, richness and challenge that attract scholars from various and diverse disciples such as theology, philosophy, history, and political science. (Pollmann, 1999) The historical backdrop to Augustine's City of God comes from the events of his day. G. R. Evans articulates the impact of the sacking of Rome in 410 which was the catalysts for Augustine to write the City of God. "Augustine was 56 in 410 when the City of Roman was sacked by Alaric the Goth. That was only one episode in a series of attacks upon the pride and security of the Roman Empire which took place in Augustine's lifetime. Various tribes were creeping progressively into accusation of imperial lands and the government increasingly found itself unable to do anything but acquiesce and give the invaders the placatory status of allier. More than any other single episode the making of Rome gave Augustine a reason to write the City of God. after 410 the found exiles, those escaping the disturbing events in Italy, arriving in North Africa where he was now Bishop of Hippo and asking hw he could explain this collapse of a Christian Empire. it was their anger changes that led him begin work on a book which was no appear in episode stretching over many years of composition" (G.R. Evans 1984) Furthermore the appalling, traumatic and tragic events of Rome being sacked was also profoundly influential in the reason, purpose, intent and meaning for the writing of the City of God.

Learning the historical events that were the background that lead to Augustine writing the City of God provides some insight into what were the reasons and purposes that prompted Augustine to write this text. Also it is evident as to what motivated Augustine was multiple reasoning Evans presents Augustine's own explanation as to his reasons for writing the City of God. "Augustine himself explains in the Retractions, which he wrote at the end of his life, what, looking back with the perspective of some distance of time, he believed he had tried to do in the City of God, 'Burning with zeal for the house of God I began to write the books of the City of God against the blasphemies and errors' of its enemies. 
He deeds the now-finished work into two big sections. The first ten books deal with the 'vain opinions' $\mathrm{f}$ the adversaries of the City of God. The second group of 12 he divides int three sections. The first is concerned with the origins of the two cities; the city of this world and the city of God. The second part covers the growth of the two cities, the third 'their due ends' The origins of the two cities are the subject of book XI - XIV, the growth of the two cites, of books xv - xvii; the ends or purposes of the two cites of Books xviii - xxiii. (G.R. Evans 1984)

According Evans another purpose that prompted Augustine was his concern and desire to keep the people untied together, to protect, and defend them is potentially the principle of all his writings. (G.R. Evans 1984) A third potential reason, that Holmes presents, for the writing of the City of God is that Augustine recognized the destruction and decline of the Roman Empire but considered it secondary to God's instruments for salvation, the visible Church and the true community of just the 'City of God. (Holmes, 1992)

Moreover G.R. Evans presents that In the writing a message of salvation to unite, protect and defend his fellow brothers and sisters in Christ, the Christian faith and the church Augustine lays the foundation by writing about what he calls a 'City of God' Augustine defines the City of God as follows: "Augustine describes a city as 'a number of people bound together by some tie of fellowship'. That makes it important to be clear what the bond consists in. In the Republic Cicero makes his character Scipio Africanus propose a basis of 'right' $r$ justice, upon which association takes place in a community, giving it order and saving it from anarchic battles for power. Augustine gives a picture of 'Scipio, the annihilator of Carthage .... discussing the state of the country when it was felt that it was domed to perish. (G.R. Evans 1984)_Furthermore Evans expands upon this by articulating that it is not surprising that Augustine is interested in the concept of 'community'. He draws on the parallels in between God's City and the one discussed by Cicero. He adapts the Cireronian definitions of a 'commonwealth' to make it fit a Christian context. It exists for the common good because it has justice at its heart, and as a community,'an association united by a common sense of right and a community of interest' Both these definitions, he argues, are truly fulfilled only 'in commonwealth whose founder and ruler is Christ.'(G.R. Evans 1984) Fortin also contributes further discussion to the defining of Augustine's City of God articulating that humanity as we know it, is divided into many cites and nations, each one of which is clearly differentiated from all others by its laws, its manners, its rite, its language and its general way of life. but more fundamentally from all the others, Scared Scripture distinguishes only two kinds of societies, to which all men of all times belongs, the city of God and the earthly city. (Fortin, 1963) Lastly Evans explains that the heavenly city....does not hesitates to obey the laws of the earthly city by which those things are designed for the support of this mortal if are regulated. Augustine brutes that Christianity makes people better citizens for the temporal city. Christian make good citizens of an ordinary political earthly city because they allow who join them to continue in any 'manner of life' any habit of dress and behavior, 'provided these do not conflict with the divine instructions'. In the City within the city, 'both kind of men.... alike make use of the things essential for this mortal life, but each has its own very different end in making use of them. (G.R. Evans 1984)

Understanding Augustine's definition of the City of God sheds light relevant to the purpose and allows for there to be comprehension of the hope and goal for the City of God. The mission of the City of God involves virtue, justice, grace, peace and a good or civil society. Fortin explains the mission of the City of God being as follows: "The virtue that characterizes the citizens as citizen and orders all itizens to the end or common good of the city is justice. Justin is the cornerstone of civil society. By regulating the relations among men it preserves peace, the intrinsic common good of society and the precondition of all the other benefits that society procures. Without peace, the "tranquility order, " no society can prosper or even subsist. Quoting Cicero with approval, Augustine denies civil society or the commonwealth as 'an assemblage (of men) associated by a common acknowledgement of right and by an community of interests; He explains 'right' by 'justice' rant by 'law' and he insists that no commonwealth can be administered without justice, for where ta here is no justice there is no right and vice versa. Existing cities are assemblages of rational beings bond together not by 'a common acknowledgement of right' but by a 'common agreement as to the objects of their love' regardless of the equality of that love $r$ the goodness or badness of its objects." (Fortin, 1963) The intended objective and purpose of the City of God is the very fulfillment and embodiment of how Augustine defined and envisioned the City of God.

In contrast to the City of God, Fortin explains, the earthly city is defined as a city characterized by its affectation of total independence and self-sufficiency and presents itself as the very antithesis of the life of obedience and of reverent submission to God. Its amnesty is the unrepresentative and unredeemed Cain, and its rebellion against God renew in its own fashion the sin of disobedience that Adam committed when he fist transgressed the divine command. (Fortin, 1963) Similarly Fortin articulates that in contrast the earthly city is guided and motivated by self-love and lives according to what Scripture calls the flesh. The term 'flesh' in the present context is not to be taken in the narrow sense, as referring only to the body and the silly pleasures. In its biblical usage it is synonymous with natural man and embraces all of man's actions and desires the extent to which they are not ordered to God as to their supreme end. (Fortin, 1963) In 
defining the two cities, comparing and contrasting and understanding Augustine's definition and vision for each city truly epitomizes and illustrates Augustine's message to his fellow brothers and sisters in Christ and the church.

The final structural aspect of Augustine's City of God is how does an individual become a member of the city of God or of the earthly city. Arguably the evidence gives indication as to whether an individual is a member of the city of God or the earthly city would be based in the attributes of virtue, justice, civil obedience and grace. Fortin explains that Augustine's view of membership of the city of God is not determined or dependent upon 'going to church', or any form of visible religious method or practice. Nor could it be taken for granted that God would choose to exercise his grace solely through the orderly machinery of the Church and its sacraments. Even the elect do not know that they are chosen; there are those who are not members of the visible Church who belong to God. (Fortin, 1963)_Also Fortin explains that Augustine states that the individual who is not a member of the citizenry of the heavenly city can find and obtain all that he or she needs in life in a well-run earthly city. Although if he or she is inwardly reborn he or she is a 'new man' and an inhabitant of the heavenly city. Thus in all appearances his or her life continues in the same place, for on earth the two cities are so throughly mixed that in their 'running' and 'use' of goods' they may be indistinguishable. (Fortin, 1963) The evidence of an individuals membership to either the earthly or heavenly city is his or her character and attributes of justice, civil obedience, virtue and is a matter of the heart that determines the fate of the soul through grace.

\section{Defining the Terms and Themes of the City of God}

In continued pursuit of one's understanding Augustine's text the City of God one should have knowledge of the central ideas, terms and themes of the text. First the city in question involves the idea of a civil society and the characteristics of that said society demonstrating attributes such as civil obedience which can be defined as partly relating to or consisting of citizens of the commonwealth, state or society. Secondly the idea of obedience in and to that society means that a citizen of a society commits to acting in adherence to the dutiful practice and norms of polite social interaction and protocol of social order or organized government. Involved in a civil, lawful and orderly society there are various types of law that individual citizens and collectively as a civil society can ascribe or adhere to such as natural law and divine law. First natural law is a principle or body of laws considered as derived from nature, right, reason, or religion and as ethically binding in human society. Although in comparison divine or eternal law is the law of the divine or God's law that is not of man or society. Also the idea of reason which is defined as being a basis or cause, as for some belief, action, fact, event or a statement presented as a justification or explanation of a belief or action, truth and divinity.

The idea of theology is defined as the field of study of God and of God's attributes in relations to the universe; study of divine things or religion. In Augustine's City of $G d$ theology comprises of three theological forms mythical, natural and civil theology. Fortin articulates that Augustine defines mythical theology as the of the poets which appeals directly to the multitude and its many gods and goddesses are revered for the sake of the temporal goods or material advantages that men hope to obtain from them in this life. (Fortin, 1963) Also Fortin explains that natural theology is defined by Augustine as being the theology of the philosophers and is monotheism. It rests on the truth of a notion of God and as such it is vastly superior to both mythical and civl theology. (Fortin, 1963) The third form of theology that Fortin discusses is that of civil theology and he states that Augustine defines this theology as the official theology of the city. It differs from natural theology in that it is polytheistic, and from mythical theology in that it prescribes the worship of the pagan gods on account of the life after death and not of this life. It is the theology that all citizens are expected to know and administer. It teaches what god or gods each man may suitably worship and what sacred rites and sacrifices he may suitably carry out. It is concerned with the good of the soul rather than that of the body and aspires to make men better by favoring the development of the political virtues. (Fortin, 1963) It is these terms and ideas that all the rest of the ideas and themes in the City of $G d$ are founded in and stem from.

The other terms and themes that need to be considered are the terms that involve the characteristics that Augustine attributes to the City of God. One essential theme in the City of God is of justice which is defined as the quality of being just; righteousness, equitableness, or moral rightness or rightfulness or lawfulness, as of a claim or title; justness of ground or reason. A second characteristic would be virtue which is defined as a moral excellence; goodness; righteousness, conformity of one's life and conduct to moral and ethical principles, uprightness. A third idea that Augustine expounds on is original sin which is defined as a depravity, or tendency to evil, held to by innate in humankind and transmitted from Adam to all humans in consequence of his sin or inclination to evil, inherent in human nature. A final central theme in the City of God that should be considered and explained is the idea of free will which is defined as being a free and independent choice; voluntary decision or the doctrine that the conduct of human beings expresses personal choice and is not simply determined by physical or divine forces. In the pursuit of comprehension of Augustine's work having obtained knowledge of these central and fundamental themes and ideas it provides for the continuing increased comprehension of the City of God as one journeys on in their quest for understanding of Augustine's work. 


\section{The Characteristics of Augustine's City of God}

\subsection{Civil Society and Civil Obedience}

Continuing on this quest of examining and comprehending the City of God one needs to turn their attention a deeper evaluation and consideration of the specific, individual and theological ideas and themes of the City of God. First of the central themes is the idea of a civil society. Augustine was a most influential man and writer who through his writing proposed most profound forward thinking. This was most evident through his presentation of his theological thoughts in the City of God where Augustine explores, explains and address the principle and idea of the civil society and Fortin gives evidence of this: "St. Augustine is the first author to deal more or less comprehensively with the subject of civil society in the light of the new situation created by the emergence of revealed religion and its encounter with philosophy in the Greco-Roman world. As a Roman he inherited and restated for his own time the political philosophy inaugurated by Plato and adapted to the Latin world by Cicero, and as a Christian he modified that philosophy to sit the requirements of the faith. He thus appears if not as the originator at least last he foremost exponent in ancient time of a new tradition of political thought characterized by its attempt to fuse or reconcile elements derived form two originally independent and hitherto unrelated sources the Bible and classical philosophy." (Fortin, 1963)

Furthermore Fortin states that according to Augustine a civil society is founded upon and based in the ideas and characteristics of justice, lawful order, virtue and these elements of a civil society must also take into account the idea of free will and grace. A civil society in traditional and classical philosophy, according to Strauss, involved the repressive action maintaining relative peace among men and in such fashion insured the minimal conditions under which the church is able to exercise its teaching and saving ministry of itself it is incapable of leading to virtue. (Fortin, 1963)

Also a civil society must require civil obedience for the purpose of law and order to maintain the good of the citizenry of that society. This is not just a matter of natural law or civility but also of a religious matter or concern of divine or eternal law. Fortin explains Augustine's position and thoughts on a civil society by presenting the following: "Its purpose is not to replace civil society but to supplement it by providing over and above the benefits conferred by it, the means of achieving a goal that is higher than any to which civil society can lead. Civil society itself continues to be indispensable in that it procures and administers the temporal or natural goods which men need her on earth and which may e used as instruments to promote the good of the soul. Hence citizenship in the city of God does not abrogate but preserves and complements citizenship in a temporal society. What is typical of Augustine's position is very precisely the twin citizenship by which one is enrolled as a member of the city God without ceasing to order his temporal life within the framework of civil society and according to its norms. The extent to which this position removes from the jurisdiction of the city and reserves for a higher authority an essential part of man's life, it claims to provide the solution sought in vain by pagan philosophers, to the problem of human being, it may be viewed as to prolonged and fulfillment of that tradition." (Fortin, 1963)

Furthermore, the principle and idea of civil obedience is not just simply a matter for society but also a religious concern and is biblically encouraged and advocated by religion, the church and the scared scriptures. Fortin presents evidence of this "It consists in saying, in substance, that Christianity does not destroy patriotism but reinforces it by making of it a religious duty. The Old Testament prophets and New Testament writers alike command obedience to civil authority and to the laws of the city, To resist these laws is to defy God's own ordinance, inasmuch as civl amity is interred by God himself as a remedy for evil and is used by him as an instrument of merit in the midst of a sinful world, as St. Paul yeah in chapter 13 of the letter to the Romans to which Augustine constantly refers tin this connection. This being the case cannot justifiably allege the service of God as a reason for shunning one's civic responsibilities or refusing submission to one's temporal rules." (Fortin, 1963)

Moreover according to Fortin Augustine takes issue with the natural law or the idea of dutiful and civil obedience by citizens is only if such practices to which are opposed to the ones that reason itself denounces as vicious or immoral. (Fortin, 1963)Also it is articulated in Fortin' text that Augustine contends that in censuring such practices and by urging adherents to abstain from these statues it would actually serve the best interests of the city. (Fortin, 1963) Furthermore, any depreciation of the fatherland, if one can really speak of a depreciation, is amply compensated for by the fact that Christianity demands and very often obtain from its followers a higher degree of morality and virtue. Thus it helps to counteract vice and corruption, which are the true cause of the wakes and decline of cites and nations. (Fortin, 1963) Fortin discusses that the goal of civil obedience and of the civil society, in accordance with Augustine, should be earthly peace, which Christians also seek. In the pursuit of this common goal, Christians and non-christians can be united and live together as citizens of the same city. (Fortin, 1963) If law and order is maintained and upheld through a society that is civil and obedient then the goal of a civil society or the city of God can be achieved. It is through the idea of a lawful, orderly and civil society that one can see that in pursuit of this goal it requires other characteristics such as justice and virtue.

\subsection{Justice}

The idea and principle of justice is the second characteristic of the City of God that Augustine extensively expounds 
upon. Although Augustine agrees with the idea and principle of justice and the necessity of this characteristic for the city of God Augustine takes issue with human or natural justice and values more eternal justice. Fortin in his text discusses Augustines' position regarding the idea of justice as follows: "His moral order is expressly rooted in a natural order established by speculative reason. Justice in the highest sense prescribes the right ordering of all things according to reason. The order requires the universal and complete subordination of the lower $t$ the higher both within man and outside of him. It exists when the body is ruled by the world, when the lower appetites are ruled by reason, and when reason itself is ruled by God. The same hierarchy is or should be observed in nicety as a whole and is encountered when virtuous subjects obey wise rules, whose minds are in turn subject to the divine law. (Fortin, 1963)

Furthermore Fortin expounds on by articulating in detail Augustine's verdict of justice by articulating the following: "Augustine's verdict concerning the fundamentally defective character of human justice is corroborated and further clarified by his analysis of law in Book I of the treatise "On Free Will." Augustine begins by distinguishing clearly between the eternal law, which is the supreme norm of justice, and the temporal or human law, which adapts the common principles of the eternal law by the changing needs of particular societies. The eternal law is defined very generally as the law 'in virtue of which it it just that all things be perfectly ordinated; and is identified with the will or wisdom of God directing justice and righteousness, and from it flows whatever is just or good mind. All are capable of knowing it and owe obedient to it all times. It is also by virtue of the eternal law that the good are rewarded and the wicked punished. Finally, the eternal law is always and everywhere the same and suffers no expectations." (Fortin, 1963)

Consequently Augustine's defined stated position and verdict on natural or human justice Strauss goes on to explain the issues that Augustine takes with this form of justice. Augustine views the temporal or natural law as not always being just and he finds it flawed with many imperfections. Fortin explains that the viewpoint of Augustine is that the temporal law is a just law, it is also in many ways an imperfect law. it exists, not primarily for the sake of the virtues, who strive of their own accord toward eternal goods and are subject only to the enteral law, but for the sake of the imperfect, who covet temporal goods and act justly only when compelled to do so by human law. (Fortin, 1963) Moreover in Fortin' text he articulates the remedy that Augustine proposes for the issues. Augustines sees regarding temporal or natural justice as follows: Justice is neither the work nor the common lot of fallen man. Even the god that is proportionate to his rational nature eludes him for the most part. The remedy to this situation is not to be found among proper resources of human nature. Man's salvation, including his political salvation, secures to him, not from philosophy, as Plato had intimated, but from God's divine grace rather than human justice is the bond of society and the true source of happiness. (Fortin, 1963)Thus Fortin presents that the whole point and argument made by Augustine on justice could be summed up in the assertion that eminent desirability of perfect human justice and at the same time its practical impossibility, philosophy discloses its own inherent limitations; thus proclaiming at least implicitly the need to supplement human justice by a higher and more genuine form of justice. (Fortin, 1963) Finally on the characteristic of justice Fortin articulates Augustine's belief in the beneficial result that would have come and can come from the true form of perfected justice should it be upheld and by practiced man and within the city of God. Thus such is the harmony which would have triumphed if man had persevere in the state of original justice. In that state man would have benefited from all the advantages of society without any of its inconveniences. They would not have been subject again to their will to other men and instead of dying with one another Fr. the possessions of earthy goods, they would have shared all things equitably in prefect amity and freedom. (Fortin 1963)

\subsection{Virtue}

Thirdly Augustine believes that the characteristic of virtue is essential to the foundation of the fabric of the city of God. In the case of virtue it is through the comparison and contrast with the defining of the opposite of virtue that one discovers Augustine's view and position of virtue. Fortin discusses the distinction made by Augustine between virtue and vice, which the implications of true virtue is Christian virtue. What establishes a person as a member of one or the other of these two cities is not the race or nation that he might claim as his own but the one that he pursues and to which he ultimately subordinates all of these actions. (Fortin,1963) Moreover Augustine held the belief that in order to determine the character of any man one had to only to consult the object of its love. In the day of the old Roman they were not just, and their city was not a true city, because the object of their passion was not virtue. (Fortin, 1963) Also, Fortin articulates, that the Romans commended courage and placed self-sacrifice and devotion to one's nation above the amenities of a quite and comfortable existence. Nonetheless this was a purely earthly goal and the efforts expended in its pursuit was the mark of greatness but not virtue. Rome, the mistress of the world, was herself dominated by the lust to conquer. (Fortin, 1963) Thus Fortin states that Augustine attributed the great men of Rome as being at best outstanding citizens of a bad city. Most of them did not even possess genuine political virtues. Their determination to excel was fed not by a desire to serve their countrymen but by the thirst for personal glory. (Fortin, 1963) Through Fortin' writing on Augustine one is provided with the excellent example of the Romans actions and choices that demonstrate what Augustine defined as vitreous or righteous and what was dishonoring, immoral and vices. Thus this demonstration of the Roman's vices and immorality illustrated 
Augustine's definition of virtue and what he envisioned the essential role of virtue and righteousness would have in the city of God and how it was to be practiced by the citizens of the city of God.

\subsection{Free Will}

Fourthly fundamentally central and essential to Augustine's City of God is the attribute of the theological idea and principle of free will. For most individuals and believers of the faith and biblical scholars or theologians the pursuit of comprehending such theological doctrines is often a challenging journey and an evolutionary process. This was no less the case for Augustine as he journeyed through his faith. It is most interesting that the theological doctrine of free will would play such a significant, fundamental and central role in the City of God in that it was the very writings of St. Paul of the book of Romans that was so instrumental in St.Augustine's conversion to the Christian faith. It is in Romans, specifically Romans 8, written by Paul that much of the evidence is presented in the making of either case, whether in favor of or not in favor, of the doctrine of free will.

At the beginning of Augustine's journey of faith Augustine contended that God did not destine anyone to be a citizen of either city. It is, for angels and the human beings, their own choice. 'We must believe that the difference had its origin in their wills and desires; those are happy who 'cling to God'. Those are wrecked who 'do not cleave to him.' Those who chose the wrong way do so because they have 'delighted in their own power and make themselves their 'own god' (G.R. Evans 1984) Moreover, as Fortin states, Augustine believed and asserted the following: Thus God knows all things before they come to pass and that men do by their free will whatever they know and sense to be done by them only because they will it. Far from destroying free choice, God's knowledge actually founds it. The answer to the question as to how these two perfections may be reconciled lies in the supreme efficacy of the divine will. God knows all things because he knows their cases because his will extends to all of them, conferring upon each the power not only to act but to act in conformity with its proper mode. (Fortin, 1963) Author Couenheven states that resulting from this theological perspective comes a potential solution through the revisions of Pelagius that free will is ultimately neutral, balance between the potentialities of God and evil: God makes human beings with a dual ability for good and evil, and then was made of ourselves what we will. This approach is compelling because it seems to solve the theological problem - making human beings, and not God, to blame for evil. (Couenheyen, 2007)

Although these beliefs regarding free will had been Augustine's theological position early in his journey of faith through Augustine's progression in his journey of faith his position on free will evolved and by the later years of Augustine's journey and life he came to hold different beliefs on the theological doctrine of free will. Once again through the influence of St. Paul and his writings Augustine came to view that the will lacked the ability 'to choose what is good or righteous as a consequence of original sin; viewing his Platonic understanding of God's immutability and unchanging law. Vivian articulates that Augustine came to believe that people's good and bad wills must be 'determined before the foundation of the world'. Thus 'human beings are able to choose to do what it right because God has changed their evil wills, which they were born into good wills. God chooses from before the foundation of the world, by God's just and eternal predestination decrees, which wills are going to be changed to the good' (Vivian, 1997)

\subsection{Grace}

Augustine includes a fifth profoundly, central and fundamentally essential characteristic into the foundation of the city of God which is the idea and principle of grace. Aside from the theological importance of grace to the Christian faith and in turn the city of God this doctrine was experienced first hand by Augustine himself in his earlier life. At the age of 11 Augustine was sent to school and there was a situation that gave Augustine his very first personal insights into the nature of sin. Augustine had this revelation when he and some of his comrades stole fruit from the garden of some neighbors. Augustine recounts the story in his work The Confessions and as he reflects back he recalls that his reasoning for his choice to steal the fruit was because 'it was not permitted' not as a result of hunger or starvation. Furthermore Augustines said that his very nature was flawed, 'it was foul, and I loved it. I love my own error - not that for which I erred, but the error itself.' As a result Augustine concluded that humanity is naturally disposed to sin, and in need of the grace of Christ.(G.R. Evans 1984) Furthermore Augustine defined grace, according to Fortin, as being given gratuitously and it can be received by many but it not merited by him, for man's merits are themselves the effect and not the principle of the grace conferred. (Fortin, 1963) Augustine's theological and doctrinal based beliefs in free will potentially influence and tie into his theological position and belief regarding grace. Thus the teaching of Augustine argues that some people are predestined by God to salvation by an eternal, sovereign decree which is not based on man's own merit or will. The saving grace which God bestows is irreversible and has unfailing results in conversion. God also grants those whom he saves with the gift of perseverance so that none of those whom God has chosen may conceivably fall away. It is through this deep, extensive and through examination of these characteristics that one discovers and understands Augustine's beliefs and principles that he presents in his work and thus the cornerstones of the City of God that it is constructed on and founded upon. 


\section{Modern Cultural and Societal Relevance of Augustine's City of God}

In considering the fundamentally central aspects of Augustine's City of God such as justice, civil obedience and order, virtue, free will and grace it becomes clear the evidence of the relevance of these elements in any modern day community or society. Communities and societies are collectively made up of individual human beings who still have the same inherent human nature as did human beings did during the time of Augustine. Thus the same things that were apart of human nature and collective communities then are still inherent to modern day societies. Moreover to have a noble, good and virtuous society the collective still needs to ascribe to, strive for and maintain the fundamental societal aspects of justice, civil order and obedience, virtue, grace and free will. Equally in modern society there is still the same cultural issues and societal concerns such as civility, order, law, ethics, morality, crime, education, cultural and societal ideologies and philosophy, religion, a system of beliefs among others. These immensely essential cultural and societal components are the fundamental fibers and foundation of any community and are what shapes and forms a society. Thus equally relevant in Augustine's day and in any modern day each community or society must evaluate these fundamentally essential societal attributes, characteristics and facets and chose whether or not they will implement these and whether to form and shape an immoral or noble community or society such as in Augustine's City of God.

\section{Conclusion}

Through extensive consideration of Augustine's profoundly and significantly influential life and work, the defining terms and ideas in the City of God, the historical framework and the defining characteristics of Augustine's City of God one undeniable fact becomes profoundly evident is that of the relevance of the City of God culturally, socially, politically and religiously during Augustine's day and modern historical eras alike. At the time that Augustine had written the City of God it was profoundly relevant in that it spoke to his fellow believers, profoundly reached them and spoke to a most traumatic and tragic event and chapter in their lives. Furthermore the issues that Augustine spoke to such as civil society and obedience, justice, virtue, free will and grace had immense cultural, social and religious impact as to what individuals believed and how they conducted their lives related to their religion, faith, culture and society. Similarly numerous of Augustine's beliefs and theological principles made a profound influential religious imprint evident by the adoption of, being practiced and implemented by the church thus becoming an inherent doctrinal aspect and belief in the church and of the faith.

These religious principles presented by Augustine are still religiously relevant today in the modern day church and Christianity. Thus this gives evidence as to how Augustine's work influenced the religion, culture and society of his day as well as future generations. These central issues in the City of God are and will always have relevance for humanity as individuals and collectively which has not inherently changed. Thus the need for and concern over civil society and obedience, virtue, grace, free will and justice will always be fundamental cornerstones to individuals, humanity and society whether in classical societies, historical eras or during eras of modern history, current day or for future historical generations to come. There is also great relevance to be found with the social issues for many of these issues discussed by Augustine influences the very fibers of the very foundation of a society's cultural, religious and political structure. This give evidence to and ensures that Augustine's work of the City of God will always have most profound, significant influence and relevance to all societies and humanity.

\section{References}

Couenhoven, J. (Sep 2007). Augustine's rejection of the free-will defense: an overview of the late Augustine's theodicy. Religious Studies, 43(3). https://doi.org/10.1017/S0034412507009018

Evans, G. R. (1984). Augustine - The City of God. Translated by Henery Bettenson. London, England, UK: Penguin Books London. pg. $\mathrm{x}-$ lvii.

Fortin, E. L. (1963). History of Political Philosophy 3rd. ed. edited by. Strauss, Leo and Cropsey, Joesph. Chicago, IL: The University of Chicago Press. pg 176-203.

Holmes, G. (1992). The Oxford History of Medieval Europe. New York, NY: Oxford University Press.

Pollmann, K. F. L. (Dec 1999). Augustine's City of God: A Reader's Guide. Church History, 68(4).

Vivian, T. (Fall 1997). St. Augustine's Dilemma: Grace and Eternal Law in the Major works of Augustine of Hippo. Anglican Theological Review, 79(4).

\section{Copyrights}

Copyright for this article is retained by the author(s), with first publication rights granted to the journal.

This is an open-access article distributed under the terms and conditions of the Creative Commons Attribution license which permits unrestricted use, distribution, and reproduction in any medium, provided the original work is properly cited. 